\title{
Role of an estuarine fisheries reserve in the production and export of ichthyoplankton
}

\author{
Eric A. Reyier ${ }^{1, *}$, Jonathan M. Shenker $^{2}$, David Christian ${ }^{3}$ \\ ${ }^{1}$ Dynamac Corporation, Mail Code: Dyn-2, Kennedy Space Center, Florida 32899, USA \\ ${ }^{2}$ Department of Biological Sciences, Florida Institute of Technology, 150 W. Univ. Blvd., Melbourne, Florida 32901, USA \\ ${ }^{3}$ St. Johns River Water Management District, 4049 Reid St., Palatka, Florida 32177, USA
}

\begin{abstract}
By protecting mature fishes, marine reserves are anticipated to increase local production of ichthyoplankton, a mechanism difficult to empirically demonstrate in most coastal settings. The estuarine fisheries reserve at Kennedy Space Center (KSC), Florida, is microtidal and largely isolated from public-access areas by natural shorelines and earthen causeways, conditions which help preserve spatial gradients in ichthyoplankton production. We examined the abundance of sciaenid (Pisces: Sciaenidae) sportfish larvae across the KSC Reserve boundary on 48 ichthyoplankton surveys from August 2002 to July 2004. Over 98\% of the 15783 larval sportfish identified were spotted seatrout Cynoscion nebulosus, southern kingfish Menticirrhus americanus and red drum Sciaenops ocellatus, which, based on their small size (mean 2.3 to $2.6 \mathrm{~mm}$ ) and distance from ocean inlets (typically 30 to $90 \mathrm{~km}$ ), were all estuarine-spawned. Significantly higher concentrations of these taxa and total fish larvae occurred in public areas, contrary to study predictions. Concentrations remained higher in public areas after standardizing catch to account for habitat variables known to influence adult spawning behavior and/or ichthyoplankton survival. Further, results of an existing estuarine circulation model reaffirm that water flow across the KSC Reserve boundary is slow, impeding passive ichthyoplankton export. These findings suggest that local harvest rates of estuarine-spawning adult sciaenid sportfish (at current levels) is a poor predictor of ichthyoplankton abundance and that the KSC Reserve may do little to enhance local recruitment for these species. Nonetheless, this management area is still likely to bolster recruitment of marine-spawning taxa on a regional scale by protecting adult fish during non-reproductive periods.
\end{abstract}

KEY WORDS: Marine reserve · Fish larvae - Sciaenidae · Indian River Lagoon · Cynoscion nebulosus $\cdot$ Sciaenops ocellatus $\cdot$ Menticirrhus americanus

\section{INTRODUCTION}

In recent years increasing emphasis has been directed toward establishing permanent spatial protection for at-risk fishery species and high-quality habitat within the boundaries of marine reserves. On a regional scale one of the greatest anticipated benefits of marine reserves is net export of ichthyoplankton (Plan Development Team 1990). Most marine fishes produce pelagic eggs and/or larvae and demonstrate an exponential increase in fecundity with size (Ault \& Olson 1996). Larger fish may also produce larvae that display higher rates of survival and growth (Birkeland
\& Dayton 2005). On an individual basis, therefore, older and larger fishes contribute disproportionately to the reproductive output of a stock. Limiting harvest of mature fishes through the use of reserves should increase spawning stock biomass, resulting in elevated egg and larval production. A high percentage of this production may be carried via ocean currents to 'downstream' habitats, reducing the risk of recruitment failure over wide areas (Roberts 1997).

Presently, little empirical data are available to demonstrate differences in ichthyoplankton production among reserves and adjacent fished areas (Warner et al. 2000, Sale et al. 2005). By design or 
necessity most existing reserves protect hard-bottom habitats and have boundaries providing no physical barrier to planktonic dispersal. Ocean currents may rapidly convey ichthyoplankton away from a reserve, so sources of recruits cannot be resolved without detailed knowledge of local hydrodynamics and larval behavior, information which is usually unavailable (although natural and artificial larval tagging techniques hold promise in this regard [Thorrold et al. 2006, Almany et al. 2007]). Reserves also commonly safeguard superior habitat (García-Charton \& PérezRuzafa 1999), so carrying capacities and species assemblages may differ across reserve boundaries. Finally, the larvae of many fishery species remain poorly described, inhibiting spatial assessments of larval abundance. Due to these limitations the few empirical studies exploring the distribution of fish larvae within and around reserves (e.g. Tilney et al. 1996, Valles et al. 2001) occurred in areas where the origin and fate of organisms was difficult to determine. Consequently, research assessing the degree to which reserves enhance ichthyoplankton production and export has consisted largely of theoretical modeling studies to resolve potential transport distances, reserve linkages and recruitment processes (e.g. Roberts 1997, Botsford et al. 2001, Paris et al. 2005, Cowen et al. 2006).

Established in 1962 to safeguard rocket launch operations, the no-entry security zone at Kennedy Space Center (KSC), Florida, serves as the oldest fully protected no-take fisheries reserve in the United States (Roberts et al. 2001) and the largest in the southeastern US enclosed within an estuary. Encompassing $33 \mathrm{~km}^{2}$ of the northern Indian River Lagoon (IRL) system, this de-facto reserve offers physical and biotic characteristics that make it uniquely well-suited for a quantitative ichthyoplankton survey across its boundary. First, due to its considerable distance $(>70 \mathrm{~km})$ from the region's narrow coastal inlets, the KSC Reserve and adjacent waters are microtidal (lunar tides $<5 \mathrm{~cm}$ amplitude) with modest intra-estuarine circulation rates and no direct connection with the Atlantic Ocean (Smith 1993, Morris et al. 2003). Second, the KSC Reserve is largely isolated from public estuarine waters by shorelines and manmade earthen causeways, confining planktonic spillover to narrow channels. Together, these conditions reduce the scope of planktonic export, thus preserving spatial gradients in ichthyoplankton production to a degree not possible in estuarine and nearshore waters under strong tidal influence. Third, fisheries habitat across the Reserve boundary is qualitatively similar in many respects, consisting of seagrass beds and an open sand/mud bottom. Finally, previous research has demonstrated that sportfish within the KSC Reserve achieve a larger mean size and exist in densities 2.4 to 12.8 times higher (depending on species) than adjacent public areas (Johnson et al. 1999). Many of these fishes, including the spotted seatrout Cynoscion nebulosus, sand seatrout/weakfish C. arenarius/regalis (which locally hybridize), red drum Sciaenops ocellatus, black drum Pogonias cromis and whiting Menticirrhus spp., all members of the family Sciaenidae, spawn within the KSC Reserve and adjacent estuary (Mok \& Gilmore 1983, Johnson \& Funicelli 1991, Rydene 2003, Reyier \& Shenker 2007) and have larvae identifiable at small sizes.

In the present study, we conducted 48 ichthyoplankton surveys over a 2 yr period to assess whether the protection afforded adult estuarine-spawning sciaenid sportfishes within the KSC Reserve results in locally elevated ichthyoplankton concentrations. For this test, we utilized general linear modeling (GLM) techniques to statistically control for habitat conditions known to influence both adult spawning behavior and survival of resulting eggs and larvae. In addition, we applied a previously developed estuarine circulation model to generate estimates of hydrodynamic exchange across the Reserve boundary, information necessary for approximating rates of ichthyoplankton export to adjacent public areas. Our results have implications specific to fisheries management within the northern IRL system, and also provide insights for improving design and placement of estuarine reserves in other regions.

\section{MATERIALS AND METHODS}

Study region. The present study was confined to the northern IRL system, east-central Florida $\left(27^{\circ} 51^{\prime} \mathrm{N}\right.$ to $28^{\circ} 44^{\prime} \mathrm{N}$ ), which is composed of 3 lagoon basins: the IRL proper, the Banana River Lagoon (BRL) and Mosquito Lagoon (ML), with a combined surface area of $830 \mathrm{~km}^{2}$ (Fig. 1). The IRL proper connects to ML through Haulover Canal and to the BRL at southern Merritt Island and the Canaveral Barge Canal through central Merritt Island. The term 'river' is a misnomer; estuarine waters are typically polyhaline with a mean water depth of only $1.5 \mathrm{~m}$. Bottom substrates consist of sand, mud and shell, with prominent seagrass beds of Halodule wrightii, Ruppia maritima and Syringodium filiforme. Most areas are far removed from the inlets that provide access to the Atlantic Ocean (by up to $90 \mathrm{~km}$ over water) and are microtidal with lunar tides 0 to $5 \mathrm{~cm}$ in amplitude. Water levels fluctuate slowly and horizontal circulation is largely wind-driven. Smith (1993) estimated that a $50 \%$ renewal with ocean water through inlets takes up to $230 \mathrm{~d}$ in portions of the northern IRL. These conditions constrain up-estuary recruitment of marine-spawned fish larvae, resulting in an ichthyoplankton assemblage composed almost 


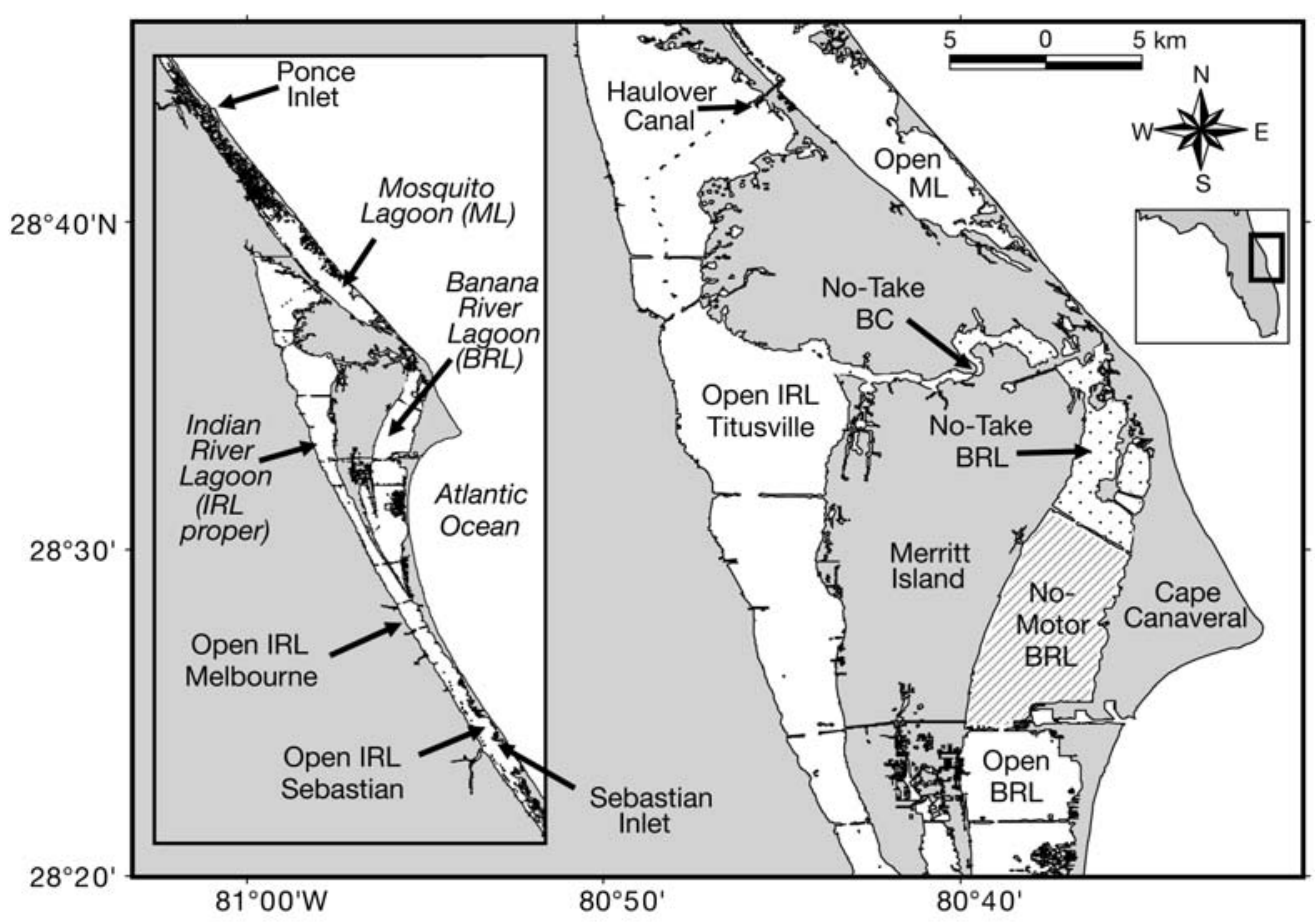

Fig. 1. The northern Indian River Lagoon (IRL) system, east-central Florida. The system is composed of 3 lagoon basins including the IRL proper, Banana River Lagoon (BRL) and Mosquito Lagoon (ML). No-Take BRL and No-Take Banana Creek (BC) (both stippled), which are not connected, lack all public access. No-Motor BRL (hatched) has limited access due to motorized vessel restrictions and temporary security restrictions. These 3 sub-basins constitute the Kennedy Space Center (KSC) Reserve. All 'Open' sub-basins have no restrictions on public access

exclusively (>99\%) of estuarine-spawned individuals (Reyier \& Shenker 2007).

Ichthyoplankton collections were confined to 8 semiisolated estuarine sub-basins with most sampling occurring within or near the boundaries of the 56700 ha KSC, whose natural areas are managed by Merritt Island National Wildlife Refuge. Four of these subbasins were primary sampling areas with surveys conducted twice monthly from August 2002 to July 2004 (48 total surveys over $2 \mathrm{yr}$ ). They are here named: (1) No-Take BRL, the northern-most sub-basin of the BRL, which was established as a no-entry security zone for KSC and the adjacent Cape Canaveral Air Force Station in 1962 and has since been unfished; (2) NoMotor BRL, the sub-basin directly south of No-Take BRL, where public access has been curtailed, but not wholly eliminated, since 1990 by a manatee sanctuary prohibiting motorized vessels; (3) Open BRL, a fully public sub-basin directly south of No-Motor BRL and outside KSC boundaries and (4) Open ML, a public sub-basin to the north of No-Take BRL separated by $<3 \mathrm{~km}$ of wetlands. The parallel goal of the present study (examined separately in Reyier \& Shenker 2007) was to resolve spatio-temporal trends in the IRL ichthyoplankton assemblage. Therefore, to expand the geographic scope of sampling, quarterly collections were made in 3 additional sub-basins each March, June, September and December. These include: (5) No-Take Banana Creek (BC), a mesohaline branch of the IRL proper, which was established as a second KSC no-entry security zone in 1962; (6) Open IRL at Titusville, a public sub-basin contiguous with No-Take BC and (7) Open IRL at Melbourne, $30 \mathrm{~km}$ south of KSC. An eighth sub-basin, Open IRL at Sebastian, was sampled in March and June 2004 to better assess estuarine ichthyoplankton communities influenced by ocean water exchange through Sebastian Inlet.

No-Take BRL, No-Motor BRL and No-Take BC, given their complete $\left(33 \mathrm{~km}^{2}\right)$ or partial $\left(57 \mathrm{~km}^{2}\right)$ public access restrictions, are herein considered the KSC Reserve. With the exception of shoreline diking of fringing salt marshes (for mosquito control purposes) and limited dredging during launch pad construction, the Reserve has received little direct impact from coastal development and exhibits healthy seagrass coverage and good water quality (SJRWMD 2002). Other study sub-basins range from near-pristine (Open $\mathrm{ML}$ ) to largely urbanized (Open BRL and Open IRL Melbourne). The KSC Reserve sub-basins are the most isolated of the IRL system; No-Take BRL connects to 
Table 1. Physical and habitat characteristics of the 8 study sub-basins of the northern Indian River Lagoon (IRL) system. BC = Banana Creek, BRL = Banana River Lagoon, ML = Mosquito Lagoon, PI = Ponce Inlet, SI = Sebastian Inlet. Area excludes adjacent impounded salt marsh. Aquatic Boundaries indicates summed width of shared aquatic connections to adjacent estuarine sub-basins. Angler density (a metric of recreational fishing pressure) is calculated from 151 Dynamac Corporation weekday aerial surveys over the KSC Reserve (No-Take BRL, No-Motor BRL, No-Take BC) from 1990 to 2004 and 37 weekday surveys over Open ML (2002 only). na = information not available

\begin{tabular}{|c|c|c|c|c|c|c|c|c|c|c|}
\hline Sub-basin & $\begin{array}{l}\text { Public } \\
\text { access }\end{array}$ & $\begin{array}{c}\text { Sampling } \\
\text { interval }\end{array}$ & $\begin{array}{c}\text { No. } \\
\text { samples }\end{array}$ & $\begin{array}{l}\text { Area } \\
\left(\mathrm{km}^{2}\right)\end{array}$ & $\begin{array}{c}\text { Mean } \\
\text { depth } \\
(\mathrm{m})\end{array}$ & $\begin{array}{c}\text { Area } \\
\text { dredged } \\
(\%)\end{array}$ & $\begin{array}{l}\text { Seagrass } \\
\text { cover } \\
(\%)\end{array}$ & $\begin{array}{c}\text { Nearest } \\
\text { inlet } \\
(\mathrm{km})\end{array}$ & $\begin{array}{l}\text { Aquatic } \\
\text { boundaries } \\
(\mathrm{km})\end{array}$ & $\begin{array}{c}\text { Angler } \\
\text { density } \\
(\text { vessels km-2) }\end{array}$ \\
\hline No-Take BRL & None & Bi-Weekly & 384 & 24.2 & 1.9 & 14.6 & 62.7 & $78.6(\mathrm{SI})$ & 0.2 & 0.00 \\
\hline No-Motor BRL & Limited & Bi-Weekly & 384 & 56.9 & 1.4 & 3.4 & 58.3 & $66.1(\mathrm{SI})$ & 0.6 & 0.08 \\
\hline Open BRL & Complete & Bi-Weekly & 383 & 25.3 & 1.5 & 3.2 & 36.9 & $60.8(\mathrm{SI})$ & 0.6 & na \\
\hline Open ML & Complete & Bi-Weekly & 384 & 38.3 & 0.9 & 0.0 & 52.2 & $42.1(\mathrm{PI})$ & 4.4 & 0.19 \\
\hline No-Take BC & None & Quarterly & 32 & 9.2 & 0.5 & 0.0 & na & $71.3(\mathrm{PI})$ & 0.8 & 0.01 \\
\hline Open IRL Titusville & Complete & Quarterly & 64 & 67.3 & 1.9 & 3.1 & 23.4 & $57.1(\mathrm{PI})$ & 1.4 & na \\
\hline Open IRL Melbourne & Complete & Quarterly & 64 & 16.3 & 1.9 & 2.3 & 28.6 & 29.9 (SI) & 2.0 & na \\
\hline Open IRL Sebastian & Complete & Twice & 18 & 21.8 & na & 6.3 & na & $0.0(\mathrm{SI})$ & 8.3 & na \\
\hline
\end{tabular}

No-Motor BRL by 2 causeway channels $(<200 \mathrm{~m}$ combined width), which itself connects to the rest of the IRL system through 3 additional channels $(<400 \mathrm{~m}$ combined width). No-Take BC adjoins the IRL proper through a natural $800 \mathrm{~m}$ wide connection. Important habitat and management characteristics of all study sub-basins are provided in Table 1.

Estuarine circulation processes. Intra-estuarine circulation rates largely dictate the degree to which the KSC Reserve can supply the region with ichthyoplankton. We applied an existing estuarine circulation model (Curvilinear Hydrodynamic 3D Indian River Lagoon Pollutant Load Reduction [CH3D IRL-PLR] model) to all 8 study sub-basins to estimate (1) the percent water volume dispersed to adjacent sub-basins in $14 \mathrm{~d}$, the near-maximum pelagic duration for most sciaenid larvae estimated from size distributions within collections, and (2) the time necessary for $50 \%$ of the water volume to be dispersed. The CH3D IRL-PLR model, developed to assess pollutant load reduction goals and test effects of causeway removal and freshwater inputs on the estuarine salinity regime and seagrass cover, employs the Eulerian approach, in which a conservative tracer is introduced into simulated flow fields and its dispersal is tracked over time (Sheng \& Paramygin 2003). This model, whose forcing mechanisms include inlet water levels, tributary inputs, non-point runoff, rain, evaporation and wind speed and direction, has been extensively evaluated in the IRL (e.g. Morris et al. 2003, Sheng \& Davis 2003, Arnold et al. 2005) but does not account for larval behavior, so its applicability requires the simplifying assumption that larvae do not enhance dispersal via active swimming or selective tidal stream transport. This assumption does not hold true for many species, but we consider this model a reasonable approximation of local dispersal since most sciaenid larvae collected were preflexion individuals ( $<3 \mathrm{~mm}$ notocord length, NL) that lacked developed fins and were poor swimmers. Further, although estuarine sciaenids often employ selective tidal stream transport (Rowe \& Epifanio 1994), the absence of tides degrades the forcing necessary to drive this mechanism. Flushing simulations were hindcast and run from 1 June 1998 until 1 January 2000, the latest period for which the model is fully calibrated. The June start date represents a time when many local estuarine fishes begin intensive spawning (Reyier \& Shenker 2007). Model runs considering only a single year do not allow comparisons of interannual variability in flushing, however simulations over larger geographic areas for the summers of 1997 and 1999 suggest that lagoonal flushing rates are similar across years (D. Christian, unpubl. data).

Ichthyoplankton collections. Ichthyoplankton surveys commenced within $48 \mathrm{~h}$ of each new and full moon, times of elevated sciaenid spawning activity in the southeastern USA (Peters \& McMichael 1987, McMichael \& Peters 1989). Most surveys (44 of 48) were conducted at night because sciaenid larvae (and many other taxa) exhibit a fairly uniform distribution in the water column at this time (Holt \& Holt 2000). Eight ichthyoplankton tows were made within most subbasins on each survey with locations chosen using a random point generator in Arcview 3.2 GIS software. Only 4 collections per survey were made in No-Take $\mathrm{BC}$ due to its relative inaccessibility (mean depth $<0.5 \mathrm{~m}$ and a low bridge that prohibits boat access to its eastern half). A ninth station was added at Open IRL Sebastian to examine larvae moving through the Sebastian Inlet. Surface plankton tows were made with a $1 \mathrm{~m} \times 0.5 \mathrm{~m} 500 \mu \mathrm{m}$ mesh neuston net (SeaGear) towed $20 \mathrm{~m}$ behind a small skiff in a wide circle. 
A flow meter was suspended across the net mouth to generate concentration estimates for fish eggs (no. $\mathrm{m}^{-3}$ ) and larvae (no. $100 \mathrm{~m}^{-3}$ ). Tow speed was held at $1 \mathrm{~m} \mathrm{~s}^{-1}$ for 4 min resulting in mean filtered water volumes $>100 \mathrm{~m}^{3}$. A different protocol was necessary in shallow No-Take BC where the net was instead fished passively in a localized wind-induced current generated by a culvert constructed within its narrow central portion. This fixed sampling site is thought to typify much of the sub-basin. Twice monthly surveys of the 4 primary sub-basins were typically completed within 1 night and expanded quarterly efforts (all 8 sub-basins) within 3 nights.

Concurrent with each sample, habitat variables known to influence adult sciaenid spawning behavior or ichthyoplankton survival were recorded. Surface water temperature $\left({ }^{\circ} \mathrm{C}\right)$, salinity (ppt) and dissolved oxygen (DO) $\left(\mathrm{mg} \mathrm{l}^{-1}\right.$ ) were measured with a YSI 6920 water meter, total water depth $(\mathrm{m})$ with a handheld depth meter and turbidity (expressed as nephelometric turbidity units, NTU) with an ES\&D (Engineered Systems \& Designs) 800 turbidity meter. Ctenophores (comb jellies, efficient ichthyoplankton predators) were quantified by measuring their displacement volume (i.e. biovolume) in a graduated cylinder. Ichthyoplankton samples were preserved in $5 \%$ formalin and returned to the lab where most larvae were removed, identified and enumerated under a stereoscope. Identification of sciaenid larvae followed Ditty (1989). Up to 10 ind. per sample of each taxa were randomly culled and measured (NL for preflexion larvae and standard length [SL] for flexion/postflexion larvae). When abundant, fish eggs, larval anchovies and gobies, and chaetognaths (arrow worms, another potential larval fish predator/competitor) were counted after sub-sampling with a Folsom plankton splitter. While many perciform families spawn pelagic eggs indistinguishable from sciaenids, none were collected as preflexion larvae; therefore all eggs with this morphology were attributed to the family Sciaenidae.

Data analyses. We sought to answer 2 questions regarding ichthyoplankton distribution across the KSC Reserve boundary: (1) Did observed concentrations of sciaenid sportfish larvae, total fish larvae and sciaenidtype eggs differ significantly between sub-basins, irrespective of habitat conditions, and (2) After accounting for the influence of measured habitat variables, did significant spatial differences in concentrations persist? The first question was addressed using only Sub-Basin and Month of Year as main effects in 2-way ANOVAs $(\alpha=0.05)$ followed by Tukey HSD post-hoc tests of observed means (Sokal \& Rohlf 1995). Year alone was not considered a main effect since sampling did not fully encompass the 2002 and 2004 spawning seasons for certain taxa. The second question was addressed using a GLM in which the main effects SubBasin and Month of Year were combined with the 7 measured habitat covariates (Type III Sum of Squares), followed when necessary by pairwise comparisons of adjusted (least squares) means using a Bonferroni correction to eliminate inflated $\alpha$ error.

Both analyses were constrained to collections from the 4 primary sub-basins (No-Take BRL, No-Motor BRL, Open BRL and Open ML) because of their high, near-simultaneous and equivalent sampling effort with separate models constructed for (1) Cynoscion nebulosus larvae, (2) Menticirrhus americanus larvae, (3) Sciaenops ocellatus larvae, (4) total fish larvae and (5) sciaenid-type eggs. To meet ANOVA/GLM assumptions of normality and homogeneity of variances, analyses only included surveys when the taxon of interest was collected: roughly May to October for C. nebulosus (24 total surveys over the 2 yr study), April to October for $M$. americanus (30 surveys), July to October for $S$. ocellatus (20 surveys), March to November for sciaenidtype eggs (34 surveys) and year-round for total fish larvae (all 48 surveys). Further, sample concentrations were averaged for each survey and resulting means were $\log (1+x)$ transformed. Prior to GLM analyses, habitat covariates were screened to ensure that they were not strongly inter-correlated and possessed linear relationships with dependent variables. GLM validity was assured through examination of residual scatterplots and normal probability plots. All calculations were performed with SPSS 12.0 software.

\section{RESULTS}

\section{Estuarine circulation processes}

Output from the CH3D IRL-PLR model demonstrates that summertime estuarine circulation within the study region is quite slow. After a $14 \mathrm{~d}$ simulation the water volume exchanged from each of the 8 study sub-basins to adjacent estuarine areas was estimated at $<37 \%$ for all sub-basins within or adjacent to the KSC Reserve (Table 2). No-Take BRL and No-Motor BRL flushed only 17.7 and $17.2 \%$ of their initial water volume, respectively, in this 2 wk span. Flushing in No-Take BC was slightly faster $(37 \%$ in 14 d) due to its wider connection to the IRL proper. The most rapid flushing occurred at Open IRL Melbourne (66.4\% flushed after $14 \mathrm{~d}$ ), a consequence of its smaller area, and Open IRL Sebastian (88.1\% flushed after $14 \mathrm{~d})$, due partly to localized tidal exchange through nearby Sebastian Inlet. The time necessary for $50 \%$ of initial water volume to be flushed was proportionally similar, ranging from $2.6 \mathrm{~d}$ at Open IRL Sebastian to between 1 and 3 mo for every sub-basin north of Open IRL Melbourne. 
Table 2. Summertime estuarine flushing rates for the 8 study sub-basins of the northern Indian River Lagoon (IRL) system as estimated by the CH3D IRL-PLR circulation model. BRL = Banana River Lagoon, BC = Banana Creek, ML = Mosquito Lagoon. The model estimates the \% volume of lagoon water advected from a study sub-basin into neighboring sub-basins over a $14 \mathrm{~d}$ interval and the time (d) necessary for $50 \%$ of a sub-basins water volume to be dispersed to adjacent sub-basins

\begin{tabular}{|lccc|}
\hline Sub-basin & $\begin{array}{c}\text { Mean } \\
\text { sub-basin } \\
\text { volume } \\
\left(10^{8} \mathrm{~m}^{3}\right)\end{array}$ & $\begin{array}{c}\text { \% water } \\
\text { volume } \\
\text { flushed } \\
\text { after 14 d }\end{array}$ & $\begin{array}{c}\text { Duration (d) } \\
\text { for 50\% } \\
\text { volume } \\
\text { flush }\end{array}$ \\
\hline No-Take BRL & 0.28 & 17.7 & 73.1 \\
No-Motor BRL & 0.91 & 17.2 & 89.1 \\
Open BRL & 0.43 & 34.3 & 29.0 \\
Open ML & 0.50 & 28.3 & 48.5 \\
No-Take BC & 0.053 & 37.0 & 28.8 \\
Open IRL Titusville & 1.20 & 22.5 & 47.8 \\
Open IRL Melbourne & 0.41 & 66.4 & 4.6 \\
Open IRL Sebastian & 0.42 & 88.1 & 2.6 \\
\hline
\end{tabular}

\section{Habitat characterization}

Mean water temperature ranged from $12^{\circ} \mathrm{C}$ each winter to $>30^{\circ} \mathrm{C}$ in summer and was consistent across sub-basins on any given survey (Table 3). Most subbasins remained polyhaline with the highest salinity consistently found in Open ML and the lowest in NoTake BC, which was usually mesohaline. DO typically fluctuated from 5 to $10 \mathrm{mg} \mathrm{l}^{-1}$ and turbidity was $<7$ NTU for most seasons and sampling locations. The highest mean turbidity was recorded from No-Take BC and a persistent north-south turbidity increase was present in the BRL. Mean water depth at collection sites ranged from 1.5 to $3.7 \mathrm{~m}$ and was greatest in NoTake BRL due to some samples taken each survey within dredged areas. Ctenophore biovolume was high (1000 to $4000 \mathrm{ml} 100 \mathrm{~m}^{-3}$ ) during winter and spring but declined precipitously from August to December. No-Take BC was the only sub-basin where ctenophores were common year-round with a mean biovolume of $5382 \mathrm{ml} 100 \mathrm{~m}^{-3}$. In contrast, chaetognath concentration peaked in summer and fall, commonly averaging 15 to 40 ind. $\mathrm{m}^{-3}$, then declining to $<5$ ind. $\mathrm{m}^{-3}$ during winter.

\section{Sportfish ichthyoplankton collections}

Between August 2002 and July 2004, a total of 592449 larval fishes were collected in 1713 plankton tows. Larvae from 5 sciaenid sportfish taxa were recorded, totaling $2.7 \%$ of the catch. They included (in order of abundance): Cynoscion nebulosus ( $\mathrm{n}=7298)$, Menticirrhus spp. ( $\mathrm{n}=6639)$, Sciaenops ocellatus $(\mathrm{n}=$ 1596), C. arenarius/regalis $(\mathrm{n}=117)$ and Pogonias cromis $(\mathrm{n}=86$, Table 4). Menticirrhus spp. larvae were attributed to $M$. americanus due to few records of adult M. saxatilis or $M$. littoralis in previous IRL ichthyofaunal surveys. In addition, 7334 unidentified sciaenid yolk-sac larvae (unclassified due to damage or pigment fading during preservation) and 2.45 million sciaenid-type eggs ( $40 \%$ of all pelagic fish eggs) were also collected. These latter 2 taxonomic groups, whose abundance may be underestimated with a $500 \mu \mathrm{m}$ mesh, include the estuarine spawning silver perch Bairdiella chrysoura, which was commonly taken as larvae ( $\mathrm{n}=5944$ ) but is not harvested by anglers due to its small adult size. Most sciaenid larvae were preflexion individuals; mean NL was only 2.3 to $2.7 \mathrm{~mm}$ depending on species. Larvae of non-sciaenid sportfishery species were rare and included the ladyfish Elops spp. ( $\mathrm{n}=41)$, Atlantic spadefish Chaetodipterus faber $(\mathrm{n}=4)$ and tarpon Megalops atlanticus $(\mathrm{n}=2)$.

Contrary to study predictions, estuarine sub-basins of the KSC Reserve exhibited lower concentrations of sciaenid sportfish larvae relative to adjacent public

Table 3. Habitat characteristics measured within the 8 study sub-basins of the northern Indian River Lagoon (IRL) system. BC $=$ Banana Creek, BRL = Banana River Lagoon, ML = Mosquito Lagoon. Values equal mean $\pm 1 \mathrm{SE}$ averaged across the 2 yr study (August 2002 to July 2004)

\begin{tabular}{|c|c|c|c|c|c|c|c|}
\hline Sub-basin & $\begin{array}{c}\text { Water } \\
\text { temperature } \\
\left({ }^{\circ} \mathrm{C}\right)\end{array}$ & $\begin{array}{c}\text { Salinity } \\
\text { (ppt) }\end{array}$ & $\begin{array}{l}\text { Dissolved } \\
\text { oxygen } \\
\left(\mathrm{mg} \mathrm{l}^{-1}\right)\end{array}$ & $\begin{array}{c}\text { Turbidity } \\
\text { (NTU) }\end{array}$ & $\begin{array}{l}\text { Depth } \\
\text { sampled } \\
\text { (m) }\end{array}$ & $\begin{array}{l}\text { Ctenophore } \\
\text { biovolume } \\
\left(\mathrm{ml} 100 \mathrm{~m}^{-3}\right)\end{array}$ & $\begin{array}{l}\text { Chaetognath } \\
\text { density } \\
\text { (no. } 100 \mathrm{~m}^{-3} \text { ) }\end{array}$ \\
\hline No-Take BRL & $24.5 \pm 0.3$ & $21.6 \pm 0.1$ & $7.0 \pm 0.1$ & $2.2 \pm 0.1$ & $3.7 \pm 0.1$ & $400.7 \pm 54.8$ & $4.3 \pm 0.4$ \\
\hline No-Motor BRL & $24.3 \pm 0.3$ & $22.2 \pm 0.1$ & $6.9 \pm 0.1$ & $3.5 \pm 0.1$ & $2.0 \pm 0.0$ & $861.6 \pm 83.0$ & $8.0 \pm 0.9$ \\
\hline Open BRL & $24.4 \pm 0.3$ & $21.8 \pm 0.1$ & $6.9 \pm 0.1$ & $3.9 \pm 0.1$ & $2.0 \pm 0.0$ & $494.2 \pm 44.1$ & $8.7 \pm 0.9$ \\
\hline Open ML & $24.0 \pm 0.3$ & $30.2 \pm 0.1$ & $6.5 \pm 0.1$ & $3.3 \pm 0.1$ & $2.0 \pm 0.0$ & $680.7 \pm 77.5$ & $11.6 \pm 0.7$ \\
\hline No-Take BC & $25.4 \pm 0.9$ & $15.5 \pm 0.6$ & $6.0 \pm 0.2$ & $9.5 \pm 0.8$ & $1.8 \pm 0.0$ & $5382.2 \pm 985.3$ & $0.2 \pm 0.1$ \\
\hline Open IRL Titusville & $25.0 \pm 0.7$ & $24.5 \pm 0.4$ & $6.4 \pm 0.2$ & $2.9 \pm 0.3$ & $2.3 \pm 0.1$ & $159.4 \pm 55.4$ & $18.2 \pm 3.3$ \\
\hline Open IRL Melbourne & $25.5 \pm 0.7$ & $21.1 \pm 0.6$ & $7.3 \pm 0.3$ & $2.5 \pm 0.1$ & $2.7 \pm 0.1$ & $129.2 \pm 57.5$ & $2.4 \pm 0.8$ \\
\hline Open IRL Sebastian & $24.6 \pm 0.1$ & $33.0 \pm 1.1$ & $5.4 \pm 0.3$ & $3.0 \pm 0.4$ & $2.4 \pm 0.3$ & $11.7 \pm 8.1$ & $6.6 \pm 1.9$ \\
\hline
\end{tabular}


Table 4. Number and lengths of sportfish ichthyoplankton collected in the northern Indian River Lagoon system, August 2002 to July 2004. Cynoscion arenarius and C. regalis hybridize locally and were not separated. Unknown sciaenid yolk-sac larvae and sciaenid-type eggs include the silver perch Bairdiella chrysoura, which is not commonly harvested by recreational anglers. na $=$ not available

\begin{tabular}{|lcccc|}
\hline Taxon (common name) & No. collected & $\begin{array}{c}\text { Mean length } \\
\text { (mm, } \pm 1 \text { SD) }\end{array}$ & $\begin{array}{c}\text { Length range } \\
\text { (mm) }\end{array}$ & $\begin{array}{c}\text { No. measured } \\
\text { Cynoscion nebulosus (spotted seatrout) }\end{array}$ \\
Menticirrhus americanus (southern kingfish) & 7298 & $2.6 \pm 0.8$ & $1.5-12.0$ & 1480 \\
Sciaenops ocellatus (red drum) & 6639 & $2.3 \pm 0.6$ & $1.4-6.0$ & 1114 \\
Cynoscion arenarius/regalis (sand seatrout/weakfish) & 1596 & $2.5 \pm 0.6$ & $1.6-6.5$ & 466 \\
Pogonias cromis (black drum) & 117 & $2.4 \pm 0.6$ & $1.7-4.8$ & 78 \\
Elops spp. (ladyfish) & 86 & $2.7 \pm 0.8$ & $2.0-7.2$ & 61 \\
Chaetodipterus faber (Atlantic spadefish) & 41 & $35.6 \pm 5.2$ & $24-45$ & 39 \\
Megalops atlanticus (tarpon) & 4 & $2.6 \pm 0.9$ & $2.0-3.8$ & 4 \\
Other & 2 & $23.0 \pm 1.5$ & $22-24$ & 2 \\
Unknown sciaenid yolk-sac larvae & & & & \\
All fish larvae & 7334 & na & na \\
Sciaenid-type eggs & 592.449 & na & na & na \\
& $2.45 \times 10^{6}$ & & & na \\
\hline
\end{tabular}

Table 5. ANOVA for differences in $\log (1+x)$ transformed ichthyoplankton concentrations between sub-basins experiencing differing fishing pressure within and adjacent to the Kennedy Space Center Reserve. ${ }^{*} \mathrm{p}<0.05,{ }^{* *} \mathrm{p}<0.01$

\begin{tabular}{|c|c|c|c|c|c|c|c|c|c|c|}
\hline \multirow[t]{2}{*}{ Main effects } & \multicolumn{2}{|c|}{$\begin{array}{c}\text { Cynoscion nebulosus } \\
\text { larvae }\end{array}$} & \multicolumn{2}{|c|}{$\begin{array}{c}\text { Menticirrhus americanus } \\
\text { larvae }\end{array}$} & \multicolumn{2}{|c|}{$\begin{array}{c}\text { Sciaenops ocellatus } \\
\text { larvae }\end{array}$} & \multicolumn{2}{|c|}{$\begin{array}{l}\text { Total fish } \\
\text { larvae }\end{array}$} & \multicolumn{2}{|c|}{$\begin{array}{l}\text { Sciaenid-type } \\
\text { eggs }\end{array}$} \\
\hline & $\mathrm{df}$ & F & $\mathrm{df}$ & F & $\mathrm{df}$ & F & $\mathrm{df}$ & $F$ & $\mathrm{df}$ & $F$ \\
\hline Sub-basin & 3 & $6.50^{* *}$ & 3 & $11.26^{* *}$ & 3 & $4.13^{*}$ & 3 & $7.66^{* *}$ & 3 & 2.28 \\
\hline Month of year & 6 & $6.06^{* *}$ & 8 & $12.49^{* *}$ & 5 & $5.70^{* *}$ & 11 & $80.07^{* *}$ & 8 & $13.55^{* *}$ \\
\hline Sub-basin $\times$ Month & 18 & 0.77 & 24 & 0.94 & 15 & 1.03 & 33 & 1.00 & 24 & 0.39 \\
\hline Error & 68 & & 84 & & 56 & & 144 & & 100 & \\
\hline
\end{tabular}

areas when averaged across spawning seasons (Table 5, Fig. 2). Within the 4 primary sub-basins, mean concentrations of Cynoscion nebulosus, Menticirrhus americanus and Sciaenops ocellatus in NoTake BRL (1.02, 1.05 and 0.28 larvae $100 \mathrm{~m}^{-3}$, respectively), were significantly lower $(p<0.05)$ than that of Open BRL, Open ML or both. Open ML produced the highest concentrations of C. nebulosus (15.7 larvae $100 \mathrm{~m}^{-3}$ ) and $S$. ocellatus (5.6 larvae $100 \mathrm{~m}^{-3}$ ) and was the only sub-basin where the few Pogonias cromis and C. arenarius/regalis were regularly collected. Open BRL displayed the highest mean concentrations of $M$. americanus (11.8 larvae $100 \mathrm{~m}^{-3}$ ) and had elevated concentrations of other sciaenids relative to other BRL sub-basins. Total fish larvae were also significantly more abundant in Open ML and Open BRL due mainly to high catch rates of anchovies and gobies (74 and $17 \%$, respectively, of all larvae collected). Mean concentration of sciaenid-type eggs from primary subbasins ranged from 11.6 to 17.8 eggs $\mathrm{m}^{-3}$ and was also lower inside the KSC Reserve, although not significantly so. For all taxa, concentration also differed significantly by Month of Year with no interactions observed between Month of Year and Sub-Basin. Larval concentrations from secondary sub-basins were not directly compared to primary sub-basins due to unequal sampling effort and dates but displayed similar abundance patterns; No-Take BC yielded only a single sciaenid egg and $C$. nebulosus larvae in quarterly collections spanning 2 years, while sciaenid larvae, total fish larvae and sciaenid-type eggs were generally abundant in Open IRL Titusville and Open IRL Melbourne.

GLM models were used to standardize ichthyoplankton catch rates from primary sub-basins by accounting for variability in habitat conditions known to influence adult spawning and/or larval survival (Table 6). Model-standardized ichthyoplankton concentrations remained higher in public areas relative to the KSC Reserve although adjusted differences were more similar across sub-basins and remained significant only for Menticirrhus americanus larvae and total fish larvae. Model fit was fairly high with $\mathrm{R}^{2}$ ranging from 0.56 for Cynoscion nebulosus to 0.90 for total fish larvae. Significant model covariates differed across taxa; Month of Year explained a significant amount of variation in all models except sciaenid-type eggs. Other significant covariates included: water temperature (positive correlation with sciaenid eggs), salinity (negative correlation with total fish larvae), DO (nega- 

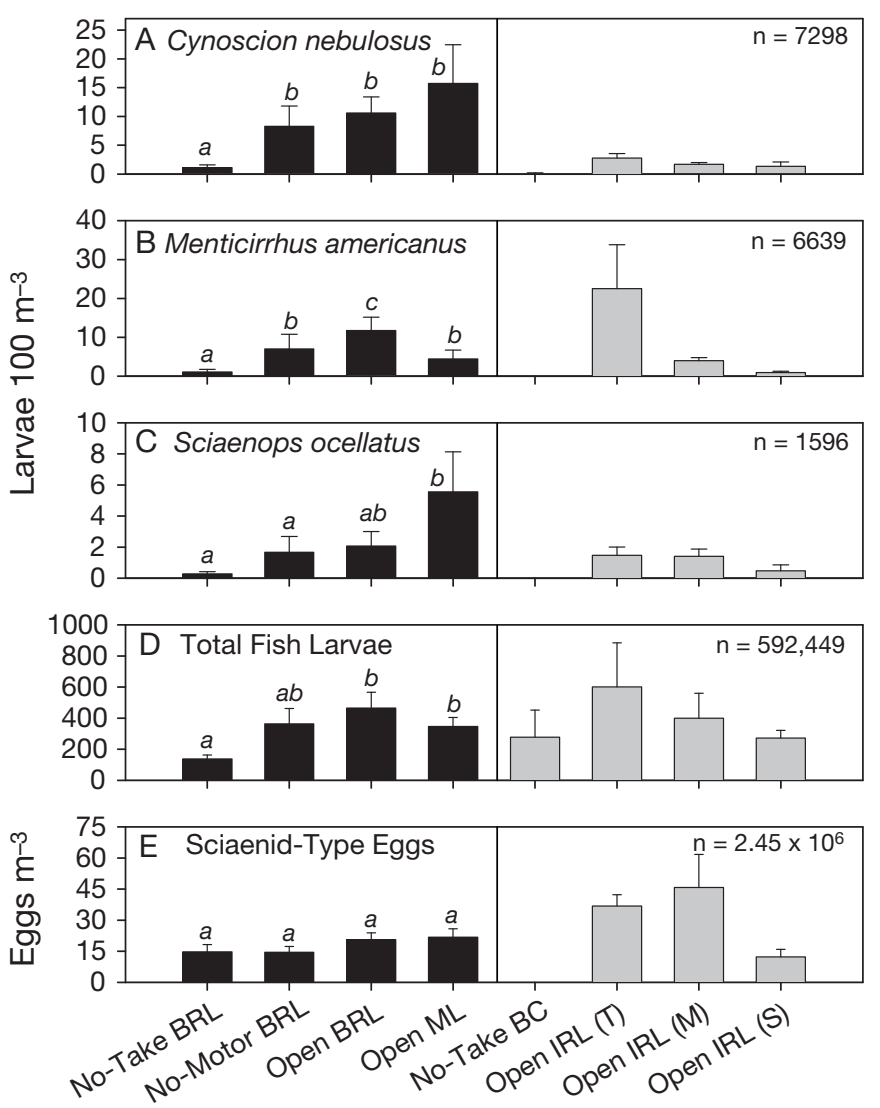

Fig. 2. Observed mean concentration (+1 SE) of Cynoscion nebulosus, Menticirrhus americanus and Sciaenops ocellatus larvae, total fish larvae and sciaenid-type eggs from both primary sub-basins (black bars, sampled twice monthly) and secondary sub-basins (gray bars, sampled quarterly) from August 2002 to July 2004 . Values were calculated by averaging concentrations across all surveys when taxa were present in the water column (ca. May to October for C. nebulosus larvae, April to October for M. americanus larvae, July to October for S. ocellatus larvae, all year for total fish larvae, and March to November for sciaenid-type eggs). Letters above error bars signify significant pairwise differences in concentrations (log 1 $+x$ transformed) between primary sub-basins as determined by a 2-way ANOVA and post-hoc Tukey Test. Note that $y$-axis scales differ among plots. T: Titusville, M: Melbourne; S: Sebastian. See Table 3 for further abbreviations

tive correlation with sciaenid-type eggs), ctenophores (negative correlation with total fish larvae and sciaenid-type eggs) and chaetognaths (positive correlation with $M$. americanus larvae, total fish larvae and sciaenid-type eggs). Turbidity and water depth sampled were insignificant in all models.

\section{DISCUSSION}

The protracted estuarine flush rates of the region, the distance from ocean inlets (up to $90 \mathrm{~km}$ ) and the high concentrations of sciaenid eggs (which hatch in
24 to $48 \mathrm{~h}$ ), together provide evidence that sciaenid sportfish larvae were collected near spawning sites, with abundance therefore largely dictated by local adult spawning stock biomass and habitat quality. Nonetheless, the KSC Reserve demonstrated reduced concentrations of these larvae relative to adjacent public areas even after accounting for several important habitat variables. In fact, although larval concentrations fluctuated appreciably among surveys, on no survey did concentrations of Cynoscion nebulosus, Menticirrhus americanus or Sciaenops ocellatus larvae in either No-Take BRL or No-Take BC exceed that of adjacent public areas. Further, while approximately $25 \%$ of preflexion sciaenids remained unidentified, these larvae were also most abundant outside the Reserve. These findings suggest that local harvest rates of adult sciaenids (at current levels) is not the principal factor regulating spatial abundance pattern of their eggs and larvae through the region and that the KSC Reserve may not directly enhance recruitment in adjacent areas, a function commonly expected of notake areas.

The simplest explanation for this observed larval distribution pattern is that current adult sportfish biomass within the KSC Reserve has changed since first reported by Johnson et al. (1999), whose sampling occurred from 1986 to 1990. This scenario, however, is not supported by ongoing monthly fisheries-independent monitoring of the IRL system, which indicates that these no-take areas continue to support greater sizes and densities of adult sportfish year-round. (Tremain et al. 2004, D. Tremain, Florida Fish and Wildlife Conservation Commission, pers. comm. 2005). Further, there is no evidence of significant surface water or sediment contamination at KSC (Schmalzer et al. 2000), an obvious concern given local rocket launch operations. Instead, we suspect that spatial variability in habitat conditions unaccounted for in the sampling protocol largely dictate local ichthyoplankton abundance either by influencing behavior of spawning adults or mediating survival of resulting eggs and larvae. However, since No-Take BC and No-Take BRL possess no direct overwater connection and differ markedly in physicochemical characteristics, ichthyoplankton abundance in each is likely governed independently by unique sets of habitat conditions.

Low ichthyoplankton concentrations in No-Take BRL were particularly paradoxical. Salinity (19 to $25 \mathrm{ppt}$ ) remained within preferred spawning ranges for Cynoscion nebulosus (Alshuth \& Gilmore 1994) and Pogonias cromis (Saucier \& Baltz 1993); ctenophore and chaetognath concentrations were generally low, and previous acoustic studies have recorded local sciaenid courtship activity (Rydene 2003, R. G. Gilmore pers. comm. 2005). We hypothesize that 2 habitat con- 
Table 6. General linear model (GLM) analyses for differences in $\log (1+x)$ transformed ichthyoplankton concentrations among sub-basins experiencing differing fishing pressure within and adjacent to the Kennedy Space Center Reserve. Adjusted means are back-transformed concentration estimates (eggs $\mathrm{m}^{-3}$ and larvae $100 \mathrm{~m}^{-3}$ ) of predicted values obtained for each sub-basin after accounting for habitat (water quality and predator) covariates. Lowercase letters denote pairwise differences in adjusted means using the Bonferroni correction. BRL $=$ Banana River Lagoon, $\mathrm{ML}=$ Mosquito Lagoon. ${ }^{*} \mathrm{p}<0.05,{ }^{* *} \mathrm{p}<0.01$

\begin{tabular}{|c|c|c|c|c|c|c|c|c|c|c|}
\hline & \multicolumn{2}{|c|}{$\begin{array}{c}\text { Cynoscion nebulosus } \\
\text { larvae }\end{array}$} & \multicolumn{2}{|c|}{$\begin{array}{c}\text { Menticirrhus americanus } \\
\text { larvae }\end{array}$} & \multicolumn{2}{|c|}{$\begin{array}{c}\text { Sciaenops ocellatus } \\
\text { larvae }\end{array}$} & \multicolumn{2}{|c|}{$\begin{array}{l}\text { Total fish } \\
\text { larvae }\end{array}$} & \multicolumn{2}{|c|}{$\begin{array}{l}\text { Sciaenid-type } \\
\text { eggs }\end{array}$} \\
\hline & $\mathrm{df}$ & $F$ & $\mathrm{df}$ & $F$ & $\mathrm{df}$ & $F$ & $\mathrm{df}$ & $F$ & $\mathrm{df}$ & $F$ \\
\hline \multicolumn{11}{|l|}{ Habitat covariates } \\
\hline Temperature & 1 & 0.08 & 1 & 1.77 & 1 & 0.28 & 1 & 1.88 & 1 & $8.62^{* *}$ \\
\hline Salinity & 1 & 0.29 & 1 & 0.60 & 1 & 2.65 & 1 & $7.37^{* *}$ & 1 & 2.49 \\
\hline Dissolved oxgen & 1 & 2.66 & 1 & 1.77 & 1 & 2.68 & 1 & 0.34 & 1 & $6.43^{*}$ \\
\hline Turbidity & 1 & 0.04 & 1 & 1.04 & 1 & 0.04 & 1 & 0.82 & 1 & 0.07 \\
\hline Depth & 1 & 0.84 & 1 & 0.15 & 1 & 0.06 & 1 & 0.07 & 1 & 1.22 \\
\hline Ctenophores & 1 & 0.22 & 1 & 0.03 & 1 & 0.49 & 1 & $5.86^{*}$ & 1 & $5.52^{*}$ \\
\hline Chaetognaths & 1 & 0.84 & 1 & $4.39^{*}$ & 1 & 3.84 & 1 & $20.09^{* *}$ & 1 & $18.13^{* *}$ \\
\hline \multicolumn{11}{|l|}{ Main effects } \\
\hline Sub-basin & 3 & 2.13 & 3 & $4.39^{* *}$ & 3 & 0.25 & 3 & $4.76^{* *}$ & 3 & 0.77 \\
\hline Month of Year & 6 & $4.66^{* *}$ & 8 & $7.37^{* *}$ & 5 & $3.01^{*}$ & 11 & $10.79^{* *}$ & 8 & 4.24 \\
\hline Sub-basin $\times$ Month & 18 & 0.67 & 24 & 0.91 & 15 & 1.25 & 33 & 1.00 & 24 & 0.79 \\
\hline Error & 61 & & 77 & & 49 & & 137 & & 93 & \\
\hline $\mathrm{R}^{2}$ & & 0.59 & & 0.72 & & 0.64 & & 0.90 & & 0.78 \\
\hline \multicolumn{11}{|c|}{ Adjusted mean density } \\
\hline No-Take BRL & & $0.92^{\mathrm{a}}$ & & $0.64^{\mathrm{a}}$ & & $0.29^{a}$ & & $120.95^{\mathrm{a}}$ & & $9.74^{\mathrm{a}}$ \\
\hline No-Motor BRL & & $4.42^{\mathrm{a}}$ & & $4.25^{\mathrm{ab}}$ & & $0.89^{a}$ & & $313.85^{\mathrm{a}}$ & & $11.48^{\mathrm{a}}$ \\
\hline Open BRL & & $7.29^{\mathrm{a}}$ & & $7.93^{\mathrm{b}}$ & & $1.17^{\mathrm{a}}$ & & $454.36^{\mathrm{b}}$ & & $19.03^{\mathrm{a}}$ \\
\hline Open ML & & $7.97^{\mathrm{a}}$ & & $2.59^{\mathrm{ab}}$ & & $3.63^{\mathrm{a}}$ & & $348.87^{\mathrm{a}}$ & & $18.88^{\mathrm{a}}$ \\
\hline
\end{tabular}

ditions persistent within this sub-basin account for the low observed larval concentrations. First, it is probable that the north-south turbidity increase documented in the Banana River parallels a north-south increase in eutrophication, a trend supported by monthly chlorophyll a sampling by the St. John's River Water Management District (SJRWMD, 2002). Estuarine eutrophication, while commonly implicated in algae blooms, DO deficiencies and seagrass declines, nonetheless increases primary production, a condition known to foster ichthyoplankton survival and growth (Grimes \& Finucane 1991, Friedland et al. 1996, Sirois \& Dodson 2000, North \& Houde 2001). Copepods, whose concentrations are invariably linked to primary production, are dominant prey for larval C. nebulosus, Sciaenops ocellatus and P. cromis (Peters \& McMichael 1987, McMichael \& Peters 1989, Holt \& Holt 2000). Limited estuarine circulation suggests that nutrient inputs from urban centers in the southern Banana River (e.g. Cocoa Beach and Merritt Island) do not elevate primary production in No-Take BRL, a condition that may contribute to locally higher larval starvation rates. This condition would also account for the concurrent north-south increase in larvae of unharvested fish taxa (e.g. anchovies and gobies), ctenophores and chaetognaths, as well as the greater disparity observed in sciaenid larval concentrations than in sciaenid egg concentrations across the No-Take BRL boundary. Fur- ther, elevated turbidity alone may enhance ichthyoplankton survival outside No-Take BRL by reducing the feeding efficiency of planktivorous fish predators (Hecht \& van der Lingen 1992, Benfield \& Minello 1996), although this factor was not supported in any model.

Recent water quality surveys of the region (independent of the present study) also demonstrate that nearbottom waters of No-Take BRL dredge holes (remnants of launch pad construction that compose $15 \%$ of this sub-basin by area) are commonly hypoxic during summer (E. Reyier unpubl. data), a result of their depth (4 to $10 \mathrm{~m}$ ) and steep walls, which inhibit vertical and horizontal mixing. Hypoxic bottom waters, a feature of many urbanizing estuaries, often contain fewer microcrustaceans, ctenophores, scyphomedusae and ichthyoplankton than overriding normoxic waters (Keister et al. 2000) and may act as an endocrine disruptor that reduces reproductive success of adult fish through several mechanisms (Wu et al. 2003). While spawning activity within hypoxic water is unlikely, eggs and small larvae entrained in this layer would suffer high mortality either through asphyxia or starvation due to reduced prey densities. Even larger larvae capable of vertical migration may become more prone to predation since they cannot utilize the refugia of benthic habitats. These dredge holes would then function as sinks, resulting in local reductions in ichthyoplankton density. 
No-Take BC, sampled less frequently than the other 2 KSC Reserve sub-basins (hence its exclusion from models), exhibited a virtual absence of sciaenid ichthyoplankton, a condition clearly influenced by its salinity regime. $\mathrm{BC}$ was generally mesohaline (mean $15.5 \mathrm{ppt}$ ), a typical state resulting from freshwater inputs through adjacent marshes (E. Reyier unpubl. data). Salinity <20 ppt reduces egg and larval survival of both Sciaenops ocellatus (Holt et al. 1981) and Cynoscion nebulosus (Alshuth \& Gilmore 1994, Kucera et al. 2002) in laboratory experiments, and Gilmore (2003) documented an aversion to reduced salinity for spawning adult IRL C. nebulosus. Low salinity in BC likely precluded spawning of adult sciaenids or forced them to seek spawning sites elsewhere in the estuary. Also of note, ctenophore biovolume in BC was among the highest recorded from a US estuary (based on values provided by Kremer [1994]) and remained elevated through summer and fall (unlike other subbasins), undoubtedly resulting in high ichthyoplankton predation rates.

The above conditions were not accounted for in the sampling protocol and may still correlate with the local level of public access, prohibiting a complete separation of the 'reserve effect' from spatial differences in habitat quality. Ideally, empirical studies assessing reserve efficacy should simultaneously survey adjacent unprotected control areas both prior to and after the enforcement of reserve boundaries (GarcíaCharton \& Pérez-Ruzafa 1999). Unfortunately, such before-after-control-impact (BACI) approaches are impossible when considering older reserves like KSC where historical data are lacking.

While the KSC Reserve may do little to export large quantities of estuarine-spawned sportfish larvae to adjacent areas, it may still play an important role in regional sportfish recruitment. For example, juvenile Cynoscion nebulosus and Sciaenops ocellatus favor seagrass because its structural complexity reduces predation risk and provides feeding opportunities (Rooker et al. 1998). The ultimate success of these species recruitment into the fishery will thus depend on both the quality and quantity of seagrass habitat in a given area. High rates of eutrophication, hypothesized here to enhance larval survival outside $\mathrm{KSC}$, may reduce seagrass coverage and in turn the survival rates of larger size classes. In the southern BRL and throughout urbanized portions of the IRL system, significant seagrass declines linked to eutrophication have already occurred (SJRWMD 2002). Theoretically, higher post-settlement sciaenid densities may therefore be achievable inside the KSC Reserve; these fish may eventually move to other areas. However, although large juveniles and adults tagged inside the KSC Reserve are known to enter the regional fishery
(Stevens \& Sulak 2001), Rydene (2003) noted reduced densities of recently settled $C$. nebulosus recruits in No-Take BRL compared to central ML (1.2 vs. 6.2 juveniles $148 \mathrm{~m}^{-2}$ seine sweeps), indicating that the ichthyoplankton pattern we observed may also be detectable in small juvenile size classes as well.

Further, although sciaenids are targeted by most local anglers, other sportfishes (e.g. ladyfish Elops spp., tarpon Megalops atlanticus, snook Centropomus undecimalus, jack crevalle Caranx hippos, sheepshead Archosargus probatocephalus and gray snapper Lutjanus griseus) show no capacity to reproduce within estuaries and instead undertake obligate spawning migrations to shelf waters. Ongoing acoustic tracking also demonstrates that while most adult red drum inhabiting KSC waters are long-term residents (E. Reyier unpubl. data), previous tag recaptures have shown that some do displace as far as coastal inlets (Stevens \& Sulak 2001, Tremain et al. 2004), possibly for spawning purposes. For these species, the KSC Reserve likely enhances egg production on a regional scale with elevated larval recruitment occurring in tidally-influenced habitats nearer coastal inlets.

The application of ecosystem-based fisheries management strategies within estuaries remains in its infancy. In the southeastern USA, few (if any) estuarine no-take zones have been established specifically for fishery management purposes. Given the rapid growth of inshore fisheries and continued coastal development, the concept of estuarine reserves may gain favor. As the first ichthyoplankton survey of a reserve in which abundance is largely attributed to conditions within the reserve itself, the present study may be used to demonstrate the potential efficacy (or lack thereof) of proposed estuarine no-take zones. In reality, however, most estuaries receive greater tidal influence than the KSC Reserve, resulting in weaker (or at least more ephemeral) gradients in salinity, turbidity and nutrients, as well as stronger currents to promote planktonic export. Even within the IRL most areas experience greater intra-estuarine and estuarine-shelf mixing than KSC and thus may serve as good candidates for reserve protection should the need arise.

The apparent inability of the KSC Reserve to enhance larval supply to adjacent areas serves to illustrate 2 important considerations when evaluating estuarine reserve design and placement in general. First, while the understanding of larval fish dispersal and recruitment processes has advanced in recent years, especially with respect to marine reserve networks, details of ichthyoplankton transport potential from most individual reserves remains largely unknown. In coastal settings the transport envelope (the region directly supplied with plankton from a reserve, sensu Roberts 1997) can be large. In estuaries however, 
bathymetry, shorelines and anthropogenic features can quickly degrade tidal amplitude, so transport envelopes may be small and spatially variable. Further, estuarine-spawning fishes may have shorter pelagic durations or behavioral mechanisms that minimize dispersal so as to minimize dispersal so that larvae are retained near appropriate settlement substrates. It cannot, therefore, be assumed that all estuarine areas supply recruits over large areas, so the expected efficacy of candidate sites should be resolved a priori by studying both local current patterns as well as the dispersal ability (i.e. pelagic larval duration) of species targeted for protection. Second, one criteria widely applied for siting existing reserves is the degree of local habitat degradation with pristine and/or biologically diverse areas often receiving priority. However, if sustainable estuarine fisheries production is a major reserve criterion, eutrophic areas should not be arbitrarily dismissed as candidate sites since their reduced carrying capacity of adult fish may be offset by elevated egg and larval fish survivorship.

Acknowledgements. We thank R. Lowers, K. HollowayAdkins and J. Drese of Dynamac Corporation for assistance with field collections. Thanks to M. Epstein of Merritt Island NWR for logistical support and W. Tweedale, E. Carter and J. Beck of SJRWMD for providing water quality, seagrass and bathymetry data, respectively. R. Cancro of Dynamac Corporation supplied aerial boat count data and J. Ditty, NMFS Galveston, verified species identification for several sciaenid taxa. Critical reviews of the original dissertation by $R$. Paperno, R. Turingan, G. Zarillo and D. Scheidt greatly improved the quality of this work. Funding was provided through the NASA Life Sciences Service Contract.

\section{LITERATURE CITED}

Almany GR, Berumen ML, Thorrold SR, Planes S, Jones GP (2007) Local replenishment of coral reef fish populations in a marine reserve. Science 316:742-744

Alshuth S, Gilmore RG (1994) Salinity and temperature tolerance limits for larval spotted seatrout Cynoscion nebulosus (Pisces: Sciaenidae). ICES CM 1994/L:17, Biological Oceanography Committee

Arnold WS, Hitchcock WL, Frischer ME, Wanninkhof R, Sheng YP (2005) Dispersal of an introduced larval cohort in a coastal lagoon. Limnol Oceanogr 50:587-597

Ault JS, Olson DB (1996) A multicohort stock production model. Trans Am Fish Soc 125:343-363

> Benfield MC, Minello TJ (1996) Relative effects of turbidity and light intensity on reactive distance and feeding of an estuarine fish. Environ Biol Fishes 46:211-216

Birkeland C, Dayton PK (2005) The importance in fishery management of leaving the big ones. Trends Ecol Evol 20:356-358

Botsford LW, Hastings A, Gaines SD (2001) Dependence of sustainability on the configuration of marine reserves and larval dispersal distance. Ecol Lett 4:144-150

> Cowen RK, Paris CB, Srinivasan A (2006) Scaling of connectivity in marine populations. Science 311:522-527
Ditty JG (1989) Separating early larvae of sciaenids from the western North Atlantic: a review and comparison of larvae off Louisiana and the Atlantic coast of the US. Bull Mar Sci 44:1083-1105

Friedland KD, Ahrenholz DW, Guthrie JF (1996) Formation and seasonal evolution of Atlantic menhaden juvenile nurseries in coastal estuaries. Estuaries 19:105-114

García-Charton JA, Pérez-Ruzafa A (1999) Ecological heterogeneity and the evaluation of the effects of marine reserves. Fish Res 42:1-20

Gilmore RG Jr (2003) Sound production and communication in the spotted seatrout. In: Bortone SA (ed) Biology of the spotted seatrout. CRC Press, Boca Raton, FL, p 177-195

Grimes CB, Finucane JH (1991) Spatial distribution and abundance of larval and juvenile fish, chlorophyll and macrozooplankton around the Mississippi River discharge plume, and the role of the plume in fish recruitment. Mar Ecol Prog Ser 75:109-119

Hecht $T$, van der Lingen CD (1992) Turbidity-induced changes in feeding strategies of fish in estuaries. S Afr J Zool 27:95-107

Holt GJ, Holt SA (2000) Vertical distribution and the role of physical processes in the feeding dynamics of two larval sciaenids Sciaenops ocellatus and Cynoscion nebulosus. Mar Ecol Prog Ser 193:181-190

Holt J, Godbout R, Arnold CR (1981) Effects of temperature and salinity on egg hatching and larval survival of red drum Sciaenops ocellata. Fish Bull (Wash DC) 79:569-573

> Johnson DR, Funicelli NA (1991) Spawning of the red drum in Mosquito Lagoon, east-central Florida. Estuaries 14:74-79

Johnson DR, Funicelli NA, Bohnsack JA (1999) Effectiveness of an existing estuarine no-take fish sanctuary within the Kennedy Space Center, Florida. N Am J Fish Manag 19: 436-453

Keister JE, Houde ED, Breitburg DL (2000) Effects of bottomlayer hypoxia on abundances and depth distributions of organisms in Patuxent River, Chesapeake Bay. Mar Ecol Prog Ser 205:43-59

Kremer P (1994) Patterns of abundance of Mnemiopsis in US coastal waters: a comparative overview. ICES J Mar Sci 51:347-354

Kucera CJ, Faulk CK, Holt GJ (2002) The effect of spawning salinity on eggs of spotted seatrout Cynoscion nebulosus Cuvier from two bays with historically different salinity regimes. J Exp Mar Biol Ecol 272:147-158

> McMichael RH Jr, Peters KM (1989) Early life history of spotted seatrout Cynoscion nebulosus (Pisces: Sciaenidae) in Tampa Bay, Florida. Estuaries 12:98-110

Mok HK, Gilmore RG Jr (1983) Analysis of sound production in estuarine aggregations of Pogonias cromis, Bairdiella chrysoura and Cynoscion nebulosus (Sciaenidae). Bull Inst Zool Acad Sini 22:157-186

Morris FW IV, Christian D, Steward J, Cullum MG (2003) Preliminary study of the effects of causeway removals in the Indian River Lagoon. St. John's River Water Management District report in support of the Indian River Lagoon north feasibility study. US Army Corps of Engineers, Jacksonville, FL

> North EW, Houde ED (2001) Retention of white perch and striped bass larvae: biological-physical interactions in Chesapeake Bay estuarine turbidity maximum. Estuaries 24:756-769

Paris CB, Cowen RK, Claro R, Lindeman KC (2005) Larval transport pathways from Cuban snapper (Lutjanidae) spawning aggregations based on biophysical modeling. Mar Ecol Prog Ser 296:93-106

Peters KM, McMichael RH Jr (1987) Early life history of the 
red drum Sciaenops ocellatus (Pisces: Sciaenidae) in Tampa Bay, Florida. Estuaries 10:92-107

Plan Development Team (1990) The potential of marine fishery reserves for reef fish management in the US southern Atlantic. NOAA Technical Memorandum NMFS-SEFC261

Reyier EA, Shenker JM (2007) Ichthyoplankton community structure in a shallow sub-tropical estuary of the Florida Atlantic coast. Bull Mar Sci 80:267-293

Roberts CM (1997) Connectivity and management of Caribbean coral reefs. Science 278:1454-1456

Roberts CM, Bohnsack JA, Gell F, Hawkins JP, Goodridge R (2001) Effects of marine reserves on adjacent fisheries. Science 294:1920-1923

Rooker JR, Holt SA, Soto MA, Holt GJ (1998) Postsettlement patterns of habitat use by sciaenid fishes in subtropical seagrass meadows. Estuaries 21:318-327

Rowe PM, Epifanio CE (1994) Tidal stream transport of weakfish larvae in Delaware Bay, USA. Mar Ecol Prog Ser 110: 105-114

Rydene DA (2003) Spotted seatrout Cynoscion nebulosus: factors affecting juvenile distribution, microhabitat selection and trophic interactions in the Banana River Lagoon and Mosquito Lagoon, Florida. PhD dissertation, Florida Institute of Technology, Melbourne, FL

Sale PF, Cowen RK, Danilowicz BS, Jones GP and others (2005) Critical science gaps impede use of no-take fishery reserves. Trends Ecol Evol 20:74-80

Saucier MH, Baltz DM (1993) Spawning site selection by spotted seatrout Cynoscion nebulosus and black drum Pogonias cromis in Louisiana. Environ Biol Fishes 36:257-272

Schmalzer PA, Hensley MA, Mota M, Hall CR, Dunlevy CA (2000) Soil, groundwater, surface water and sediments of Kennedy Space Center, Florida: background chemical and physical characteristics. NASA Technical Memorandum 2000-208583p, Kennedy Space Center, FL

Sheng YP, Davis JR (2003) Indian River Lagoon Pollutant Load Reduction (IRLPLR) model development project, final report. I. A 3-D IRL hydrodynamics/salinity model (UF-CH3D). Civil \& Coastal Engineering Department, University of Florida, Gainesville, FL

Editorial responsibility: Jon Hare, Narragansett, Rhode Island, USA
Sheng YP, Paramygin V (2003) Indian River Lagoon Pollutant Load Reduction (IRLPLR) model development project, final report. Refined segmentation of the Indian River Lagoon estuarine system. Civil and Coastal Engineering Department, University of Florida, Gainesville, FL

Sirois P, Dodson JJ (2000) Influence of turbidity, food density and parasites on the ingestion and growth of larval rainbow smelt Osmerus mordax in an estuarine turbidity maximum. Mar Ecol Prog Ser 193:167-179

SJRWMD (St. Johns River Water Management District) (2002) Indian River Lagoon surface water improvement and management plan (SWIM), 2002 update. St. John's River Water Management District, Palatka, FL

- Smith NP (1993) Tidal and nontidal flushing of Florida's Indian River Lagoon. Estuaries 16:739-746

Sokal RR, Rohlf FJ (1995) Biometry. W.H. Freeman, New York

Stevens PW, Sulak KJ (2001) Egress of adult sport fish from an estuarine reserve within Merritt Island National Wildlife Refuge, Florida. Gulf Mex Sci 2:77-89

> Thorrold SR, Jones GP, Planes S, Hare JA (2006) Transgenerational marking of embryonic otoliths in marine fishes using barium stable isotopes. Can J Fish Aquat Sci 63: 1193-1197

Tilney RL, Nelson G, Radloff SE, Buxton CD (1996) Ichthyoplankton distribution and dispersal in the Tsitsikamma National Park Marine Reserve, South Africa. S Afr J Mar Sci 17:1-14

Tremain DM, Harnden CW, Adams DH (2004) Multidirectional movements of sportfish species between an estuarine no-take zone and surrounding waters of the Indian River Lagoon, Florida. Fish Bull (Wash DC) 102:533-544

Valles H, Sponaugle S, Oxenford HA (2001) Larval supply to a marine reserve and adjacent fished area in the Soufriere Marine Management Area, St. Lucia, West Indies. J Fish Biol 59a:152-177

Warner RR, Swearer SE, Caselle JE (2000) Larval accumulation and retention: implications for the design of marine reserves and essential fish habitat. Bull Mar Sci 66: 821-830

Wu RSS, Zhou BS, Randall DJ, Woo NYS, Lam PKS (2003) Aquatic hypoxia is an endocrine disruptor and impairs fish reproduction. Environ Sci Technol 37:1137-1141

Submitted: February 7, 2007; Accepted: October 25, 2007

Proofs received from author(s): April 11, 2008 